2 Bruce M, Will RG, Ironside JW, McConnell I, Drummond D, Suttie A, et al. Transmissions to mice indicate that 'new variant' CJD is caused by the BSE agent. Nature 1997;389:498-501.

3 Hill AF, Desbruslais M, Joiner S, Sidle KCL, Gowland I, Collinge J, et al The same prion strain causes VCJD and BSE. Nature 1997;389:448-50.
4 Homer AC, Honaver M, Lantos PL, Hastie IR, Kellett JM, Millard PH Diagnosing dementia: do we get it right? BMJ 1988;297:894-6.

5 Cousens SN, Vynnycky E, Zeidler M, Will RG, Smith PG. Predicting the CJD epidemic in humans. Nature 1997;385:197-8.

(Accepted 6 March 1998)

\section{Diagnosing fever by touch: observational study}

\author{
Katherine Whybrew, Matthew Murray, Colin Morley
}

Fever is a useful indicator of whether a child is seriously ill. ${ }^{1}$ Many mothers and doctors estimate children's temperature by touch. ${ }^{2}$ We assessed whether mothers and medical students could use touch to determine if children had fever.

\section{Subjects, methods, and results}

During their elective in a Zambian hospital, medical students and the child's mother felt children's abdomen, forehead, and neck and independently recorded whether the child felt hot. Simultaneously, a mercury thermometer was used to measure axillary temperature for exactly 3 minutes. Rectal temperature measurement was not permitted at this hospital.

In total, 1090 children aged 1 month to 16 years (median 2 years) were studied. The mean ambient temperature was $24.5(\mathrm{SD} 2.0)^{\circ} \mathrm{C}$; the mean axillary temperature from 24 children not recently vaccinated and with no complaint was 36.7 (2SD 1.12$)^{\circ} \mathrm{C}$. Therefore $37.8^{\circ} \mathrm{C}$ or higher was defined as a fever. With this definition, 236 (27\%) children had fever.

The mothers assessed 862 children and thought $574(67 \%)$ were warm or hot. Their sensitivity was $94 \%$ (221/236), specificity 44\% (273/626), positive predictive value $39 \%(221 / 574)$, and negative predictive value $95 \%(273 / 288)$.

Two students assessed 1086 children and thought $525(48 \%)$ were warm or hot. Their sensitivity was $94 \%$ (257/274), specificity $67 \%(544 / 812)$, positive predictive value $49 \%$ (257/525), and negative predictive value $97 \%$ (544/561). Two students, working independently, had remarkably similar results (sensitivities $95 \%$ and $94 \%$, positive predictive values $50 \%$ and $47 \%$ ). The table shows the data for the two groups.

\section{Comment}

This study showed that when mothers and medical students felt the children they rarely missed a child with fever, but they overestimated the number who had fever.

Because it was impractical to measure rectal temperature for cultural reasons, axillary temperature had to be used. Axillary temperature is not always accurate. One study comparing axillary and rectal temperature found means of $36.8^{\circ} \mathrm{C}$ and $37.4^{\circ} \mathrm{C}$, respectively, and a median difference of $0.5^{\circ} \mathrm{C}$ (range $-1.0^{\circ} \mathrm{C}$ to $\left.3.2^{\circ} \mathrm{C}\right)^{3}$ The difference was largest in children with high fever. The shortcomings of axillary temperature measurement might have influenced our results: positive predictive values might have been higher if rectal temperature been used.
These children felt warmer than did children in Britain, possibly because of the higher ambient temperature and the tendency to overdress. Therefore, rather than use a range derived from a different population, we calculated a normal range for the group. Defining fever as a temperature of $37.8^{\circ} \mathrm{C}$ or more was higher than the temperature used in other studies $\left(37.2^{\circ} \mathrm{C},{ }^{3} 37.4^{\circ} \mathrm{C},{ }^{4}\right.$ and $\left.37.5^{\circ} \mathrm{C}^{5}\right)$. In our study the thermometer was assiduously kept in the axilla for 3 minutes. In other studies the temperature was taken for a shorter time, which may account for the lower temperatures used.

A recent African study investigated the ability of patients (1606 men and children) or their carers to decide whether they had a fever. ${ }^{5}$ Twenty per cent had fever, but only $28 \%$ of those thought to have fever did; of those thought to have a normal temperature, $92 \%$ did.

These two studies establish that, as a screening procedure, touch will seriously overestimate the incidence of fever, but with touch, fever will rarely be missed; also, a patient who does not feel hot is very likely not to have fever. A child who feels hot needs to have a temperature taken before fever is diagnosed.

Thanks to the parents and children who took part in the study and the helpful staff of Chikankata Hospital, Zambia.

Contributors: KW and MM collected the data and were closely involved in data analysis and presentation. CM suggested the project, helped with data analysis and presentation, and is guarantor for the paper.

Funding: Financial assistance from the Commonwealth Foundation; Churchill College, Cambridge; Pembroke College, Cambridge; Medical Defence Union; Lady Valerie France; John Zeal.

Conflict of interest: None.

1 Morley CJ, Thornton AJ, Cole TJ, Hewson PH, Fowler A. Baby Check: scoring system to grade the severity of acute systemic illness in babies under 6 months old. Arch Dis Child 1991;66:100-5.

2 Clarke S. Use of thermometers in general practice. BMJ 1992;304:961-3.

3 Morley CJ, Hewson PH, Thornton AJ, Cole TJ. Axillary and recta temperature. Arch Dis Child 1992;67:122-5.

4 Shann F, MacKenzie A. Comparison of rectal, axillary and forehead temperatures. Arch Ped Adolesc Med 1996;150:74-8.

5 Einterz EM, Bates ME. Fever in Africa: do patients know when they are hot? Lancet 1997;350:781.

(Accepted 2 February 1998)

Determination of fever in children by mothers and medical students and by axillary temperature $\geqslant 37.8^{\circ} \mathrm{C}$

\begin{tabular}{lccr} 
& \multicolumn{2}{c}{ Axillary temperature } & \\
\cline { 2 - 3 } & $\mathbf{3 7 . \mathbf { 8 } ^ { \circ } \mathbf { C }}$ & $<\mathbf{3 7 . 8 ^ { \circ } \mathbf { C }}$ & Total \\
\hline Mothers: & 236 & 626 & 862 \\
\hline Child feels warm or hot & 221 & 353 & 574 \\
\hline Child feels normal or cold & 15 & 273 & 288 \\
\hline Students: & 274 & 812 & 1086 \\
\hline Child feels warm or hot & 257 & 268 & 525 \\
\hline Child feels normal or cold & 17 & 544 & 561 \\
\hline
\end{tabular}

\section{University of Cambridge, Department of Paediatrics, Box 226 Neonatal Intensive Care Unit, \\ Addenbrooke's \\ Hospital, Cambridge CB2 2QQ \\ Katherine \\ Whybrew, medical student \\ Matthew Murray, medical student Colin Morley, honorary consultant paediatrician \\ Correspondence to: Dr Morley morleyc@cryptic. rch.unimelb.edu.au}

BMJ 1998;317:321 